Article

\title{
Study of Hard and Soft Countermeasures for Scour Protection of the Jacket-Type Offshore Wind Turbine Foundation
}

\author{
Hsin-Hung Chen ${ }^{1,3, \dagger}$, Ray-Yeng Yang ${ }^{1,2, \dagger}$ and Hwung-Hweng Hwung ${ }^{2,3, *}$
}

1 Tainan Hydraulics Laboratory, National Cheng Kung University, 5th Floor, No. 500, Section 3, Anming Road, Tainan 709, Taiwan; E-Mails: hander@mail.ncku.edu.tw (H.-H.C.); ryyang@mail.ncku.edu.tw (R.-Y.Y.)

2 International Wave Dynamics Research Center, National Cheng Kung University, 2nd Floor, No. 500, Section 3, Anming Road, Tainan 709, Taiwan

3 Department of Hydraulic and Ocean Engineering, National Cheng Kung University, No. 1, University Road, Tainan 701, Taiwan

$\dagger$ These authors contributed equally to this work.

* Author to whom correspondence should be addressed; E-Mail: hhhwung@ mail.ncku.edu.tw; Tel.: +886-6-275-7575 (ext. 50005); Fax: +886-6-274-3981.

Received: 18 February 2014; in revised form: 5 May 2014 / Accepted: 20 May 2014 / Published: 2 July 2014

\begin{abstract}
Physical model tests with the scale of 1:36 are carried out in the Near-Shore Wave Basin (NSWB) at Tainan Hydraulics Laboratory (THL) with the jacket-type offshore wind turbine foundation (jacket-type foundation) and the combination of hard or soft scour protection in the test area. Scouring around the jacket-type foundation exposed to wave and current was conducted in the NSWB with a mobile bed experiment. Two locations (a water depth of $12 \mathrm{~m}$ and $16 \mathrm{~m}$ ) of the foundations are separately simulated in this study. Based on the analysis from the former NSWB experimental results, one traditional hard scour protection usually used in Taiwan with four layers around the foundation is proposed for the mitigation of scouring. From the experimental results, a four-layer scour protection is tested and found to be effective in preventing scouring around the jacket-type foundation. Besides the hard scour protection countermeasure, the scour protection effect of an integrated offshore wind turbine and cage net aquaculture facility as a soft countermeasure for scour protection of the jacket-type foundation is further evaluated in this study.
\end{abstract}


Meanwhile, a detailed analysis for stakeholders' opinions on the integration of offshore wind farms and coastal aquaculture is also considered to obtain important experience and knowledge; and furthermore, to understand the real demand for adjusting the feasibility of this soft countermeasure.

Keywords: scour; jacket-type foundation; mobile bed experiment; hard scour protection; soft scour protection; stakeholder

\section{Introduction}

The growing concern in the 1990s over $\mathrm{CO}_{2}$-forced global warming has given new life to the prospects for the greater use of wind turbines, because of their credentials as non-polluting generators powered by winds created by solar energy, a renewable resource. Over the past two decades, on-shore wind energy technology has forecasted a ten-fold reduction in cost and currently has become competitive with fossil and nuclear fuels for electric power generation worldwide. As a direct consequence of the Kyoto Protocol, there is a new impetus in developing the capacity of offshore wind farms to provide a significant percentage of the target renewable energy quota. Offshore wind energy began in the shallow waters of the North Sea, where the abundance of sites and higher wind resources were more favorable by comparison to Europe's land-based alternatives. All of today's offshore wind farms producing energy (starting 2007) are located in shallow waters; they are either founded on monopiles or on gravity-based caissons [1]. However, the transitional substructure of the offshore wind turbines will be replaced by fixed bottom systems that use a wider base with multiple anchor points, like those frequently used in the oil and gas industry.

Up to June 2010, the capacity of wind power facilities built on land reached 424.2 MW in Taiwan. However, land areas with high wind energy potential and good environmental conditions for construction are limited. If the offshore wind power technology and the actual installed capacity have substantial progress in the future, these will help to increase the proportion of wind power distribution in Taiwan. The national target on the renewable energy ratio in Taiwan is expected to reach $15.1 \%$ by the year 2025; herein, 5.3\% accounted for wind power. In comparison with all other renewable energy in Taiwan, wind power has a higher potential for use and is expected to grow rapidly, showing the importance and urgency. When we consider water depths at $5 \mathrm{~m}-20 \mathrm{~m}$ for the western coastal water, the total area is approximately 120,000 hectares, with speeds greater than $6 \mathrm{~m} / \mathrm{s}$ at $50 \mathrm{~m}$ above sea level. If 3-MW wind turbines are respectively arranged with intervals of four- and 10-times the rotor diameter, according to a perpendicular and parallel wind orientation, the total installation of wind turbines is initially estimated to be about 3000 units, which provides approximately a wind power potential of $9 \mathrm{GW}$ at sea. However, because Taiwan has a unique geographic environment with a high potential for natural disasters from typhoons and earthquakes, the experiences of offshore wind power development from Northern Europe are difficult to directly transfer for domestic usage. After excluding offshore regions of limited development and considering safety and environmental issues, the total of wind turbines that can be installed is around 400 units. The development of electrical capacity by offshore wind power is approximately $1.2 \mathrm{GW}$. 
In Taiwan, a range of seabed locations from Chang-Hwa to Yun-Lin and the mid-western coast have been licensed for the development of offshore wind farms. One of the key factors in building offshore wind farms is the influence of the seabed geology and sedimentary environment on the foundation design and stability over the lifetime of the structure. Regarding foundations for offshore wind turbines, it is well known that in most cases, scouring phenomena occur around the foundations, owing to the presence of the complex supporting structure and inducing changes in the natural flow regime at the sea bed around the supporting structure, leading to increased sediment mobility [2]. Therefore, the objective of this study is to improve the understanding of the scouring behavior and to design scour protection systems for offshore jacket-type foundations located on a sandy seabed. In order to describe the physical processes and influencing factors on scour progression from a scientific point of view, comprehensive investigations on the scouring phenomena for jacket-type foundations have been carried out in this study. A physical model test study has been performed on the occurrence and prevention of erosion holes (scouring) around the jacket-type foundations of offshore wind turbines on sandy soils. The scouring around the jacket-type foundation exposed to wave and current is conducted in the Near-Shore Wave Basin (NSWB, $150 \mathrm{~m} \times 60 \mathrm{~m} \times 1.5 \mathrm{~m}$ ) of Tainan Hydraulics Laboratory (THL) with a 1:36 scale mobile bed experiment. Two locations (a water depth of $12 \mathrm{~m}$ and $16 \mathrm{~m}$ ) for the foundation are separately simulated in this study. The maximum scour depth and the potentially impacted scour area around the jacket-type foundation are analyzed from the results of the mobile bed experiment. In order to prevent erosion, one of the suitable scour protections with a rock dump layer, a traditional hard countermeasure, is firstly proposed to reduce the impact of scouring. Meanwhile, this study also evaluates the feasibility of an integrated offshore wind turbine foundation with a cage net aquaculture facility with respect to the effect as a soft scour protection.

In public management and arrangement, the stakeholders are defined as: "anyone, any group or organization that could be effected by the results from noticed things or resources" [3]. According to the standpoint of each stakeholder [4], as well as the importance in a project, used two indexes to divide stakeholders into four categories, including advocates, antagonistic, low priority and problematic, and then established corresponding strategies, respectively, according to the analysis matrixes of the stakeholders. In natural resource management, collaboration management is usually applied to the analyses of stakeholders. Collaboration management is a continually process of coordination, learning and modification. The first stage of the entire process is mainly to organize a partnership [5]. Through collaboration management, the primary stakeholders can play an actually influential role, even entering the management level or participating in decision-making, establishing a continuous learning-by-doing partnership, fulfilling management rules that can be accepted by both parties and that are constrained by legal force, and continuously advancing the capability and responsibility of the stakeholders [5]. In terms of ocean or costal management, the participation of stakeholders should maintain its original value instead of a measure for smooth management execution or the reinforcement of project influence [6]. Thus, after the feasibility evaluation of an integrated offshore wind turbine foundation with cage net aquaculture as a soft scour protection, the preliminary analysis for stakeholders' opinions is also investigated to understand the possibility of this combination in marine space utilization off the coast of western Taiwan. 


\section{Hydrodynamic and Morphologic Background}

Offshore wind turbines are currently perceived as one of the most environmentally friendly sources of electrical power and a non-polluting renewable resource that causes minimal human, ecological and environmental impacts. Offshore wind farms are now being proposed for, or built in, increasingly hostile hydrodynamic environments. Many prospective or potential sites for offshore wind turbine parks are located on a seabed of mobile sediments in the mid-western coastal area of Taiwan (the Chang-Hwa and Yun-Lin water area). Thirty sets of 3.6-MW (or 5-MW) jacket-type offshore wind turbines will be established under the plan of Taiwan Power Company (TPC) before 2015. The range of water depth for this offshore wind turbine park is located from $10 \mathrm{~m}$ to $20 \mathrm{~m}$ with a mild slope bottom ( $\mathrm{S}=1 / 150 \sim 1 / 600)$. The sediment in situ is fine sand of a median diameter of $\mathrm{d}_{50}=0.2 \mathrm{~mm}$ and a specific gravity of $\gamma_{\mathrm{s}}=2.65$ for natural sand. Two locations (a water depth of $12 \mathrm{~m}$ and $16 \mathrm{~m}$ ) for the wind turbine foundation (shown in Figure 1) are simulated respectively in this study. Although the life cycle of the wind park is 20 years, due to the consideration of extreme wave loading, the model has to be performed in a 1:100 year return period typhoon wave for the short-term impact and critical monsoon wave for the long-term loading. The maximum local current of this area is $1.0 \mathrm{~m} / \mathrm{s}$, which is a depth-averaged current for both tidal and wind-driven currents. The angle between the incident wave and current is around $90^{\circ}$. Due to the high tidal range of the studied area, different water levels are also considered for every test. All the test conditions of the mobile bed experiment in this study are shown in Table 1.

Figure 1. A sketch of the two locations (a water depth of $12 \mathrm{~m}$ and $16 \mathrm{~m}$ ) of the jacket-type foundation (EL, Elevation; LAT, lowest astronomical tide; MWL, mean water level; HHWL, higher high water level).
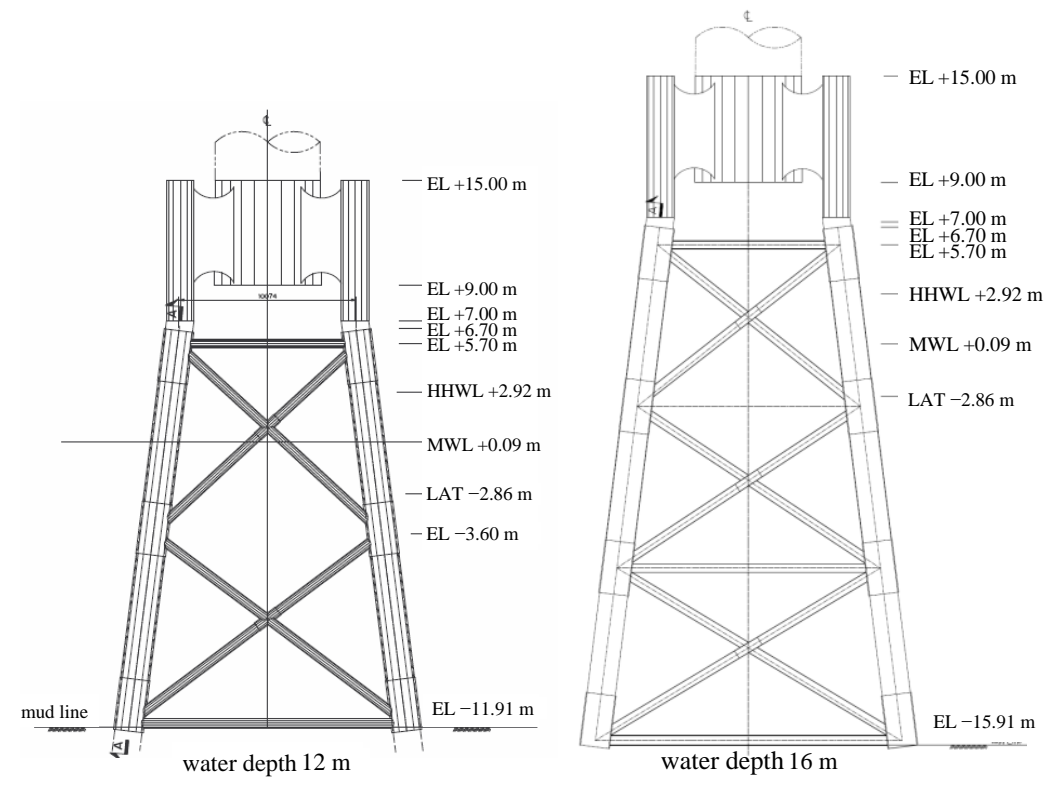

Several series of physical model tests are performed in this study. The aim of the first test is to investigate the largest magnitude of local scouring and the potential scour area in the sand bed around the jacket-type foundation with no scour protection. The other series of tests aim at the level of 
protection for the proposed hard or soft scour mitigation under the designed wave and current conditions and to assess the extent of scouring around the foundations. The layout of the $7 \mathrm{~m} \times 5.4 \mathrm{~m}$ wave-current basin for the scour testing area is shown in Figure 2. The wave flume passes from right to left, and the current generation flume circulates from the downside to the upside. The test area with the jacket-type foundation is at the junction of these two flumes. The physical modeling is carried out in this wave current basin at the Tainan Hydraulics Laboratory (THL) with a scale of 1:36. Froude's law is obeyed in the experiment. Regarding the physical model law [7], the mobile bed experiments are tested based on the Shields number. Thus, based on Shields number simulation, the sediment used in this experiment is light density coal (specific gravity of coal, $\gamma_{c}=2.02$ ) of a median grain size of $\mathrm{d}_{50}=0.15$ $\mathrm{mm}$, and the model sand bed is $0.35 \mathrm{~m}$ deep, $7.0 \mathrm{~m}$ long and $5.4 \mathrm{~m}$ wide. The equipment and measurement systems used in this experiment include an irregular wave maker, a current generation system, electrical capacitance wave gauges, acoustic doppler velocimeters (ADV) and an ultrasonic bottom profiler moved by the carriage table $(7 \mathrm{~m} \times 6.0 \mathrm{~m})$.

Table 1. Test conditions of the mobile bed experiment.

\begin{tabular}{|c|c|c|c|c|c|c|}
\hline Test Case & $\begin{array}{c}\text { Water } \\
\text { Depth } \\
(\mathbf{m}) \\
\end{array}$ & $\begin{array}{c}\text { Wave } \\
\text { Height } \\
\text { (m) } \\
\end{array}$ & $\begin{array}{c}\text { Wave } \\
\text { Period } \\
\text { (sec) }\end{array}$ & $\begin{array}{c}\text { Water Level } \\
\text { (m) }\end{array}$ & $\begin{array}{c}\text { Tidal } \\
\text { Current } \\
(\mathbf{m} / \mathbf{s}) \\
\end{array}$ & $\begin{array}{c}\text { Wave } \\
\text { Spectrum }\end{array}$ \\
\hline 12TLL(C)M & \multirow{5}{*}{12.0} & \multirow{2}{*}{6.77} & \multirow{2}{*}{11.74} & LLWL + storm surge $(-1.56)$ & $0.0 / 1.0$ & \multirow{10}{*}{ Jonswap } \\
\hline $12 \mathrm{TM}(\mathrm{C}) \mathrm{M}$ & & & & MWL + storm surge $(+1.39)$ & $0.0 / 1.0$ & \\
\hline 12SLL(C)M & & \multirow{3}{*}{2.5} & \multirow{3}{*}{7.0} & LLWL (-2.86) & $0.0 / 1.0$ & \\
\hline 12SL(C)M & & & & $\operatorname{LWOST}(-2.13)$ & $0.0 / 1.0$ & \\
\hline $12 \mathrm{SM}(\mathrm{C}) \mathrm{M}$ & & & & MWL (+0.09) & $0.0 / 1.0$ & \\
\hline 16TLL(C)M & \multirow{5}{*}{16.0} & \multirow{2}{*}{7.72} & \multirow{2}{*}{11.67} & LLWL + storm surge $(-1.56)$ & $0.0 / 1.0$ & \\
\hline $16 \mathrm{TM}(\mathrm{C}) \mathrm{M}$ & & & & MWL + storm surge $(+1.39)$ & $0.0 / 1.0$ & \\
\hline 16SLL(C)M & & \multirow{3}{*}{2.5} & \multirow{3}{*}{7.0} & LLWL (-2.86) & $0.0 / 1.0$ & \\
\hline 16SL(C)M & & & & $\operatorname{LWOST}(-2.13)$ & $0.0 / 1.0$ & \\
\hline $16 \mathrm{SM}(\mathrm{C}) \mathrm{M}$ & & & & MWL (+0.09) & $0.0 / 1.0$ & \\
\hline
\end{tabular}

Notes: the water level deviation for a 100 -year return cycle storm surge is $1.3 \mathrm{~m} ; 12,12-\mathrm{m}$ water depth; T, 100-year return period typhoon wave; S, monsoon wave; LL, lower low water level (LLWL); M (1st), mean water level (MWL); L, low water of ordinary spring tide (LWOST); C, current; M (last), mobile bed.

The ultrasonic bottom profiler system used in this experiment is the 5-MHz Ultrasonic Ranging System from SeaTek Company; its ultrasonic probe can continuously measure the dynamic changes in the bottom profiler. There are 12 transducers included in this system, and all of the transducers are housed in stainless steel housings. The transducers operate at $5 \mathrm{MHz}$, have a half beam angle of 0.9 degrees and a transducer diameter of $1 \mathrm{~cm}$. The closest range measurement of this system is $3 \mathrm{~cm}$; the furthest range is $110 \mathrm{~cm}$; the measurement accuracy is $1 \mathrm{~mm}$. When measuring the bottom profiler, the jacket-type foundation model could be taken up, and then, the changes in the surrounding and the inside seabed of the jacket-type foundation model could be thoroughly measured. Before and after the wave-current action for several runs in each test, the bottoms of the model sand beds are scanned line-by-line along the carriage table. Then, the evolution of the topography of the sea bottom and the scouring around the jacket-type foundation can be analyzed from the measurement data of the 
ultrasonic bottom profiler. In general, a coastal topography test model and the sedimentation between the model and the field must meet the mobility number (or Shields parameter) similarity. In order for the currently used model bottom material (coal) to completely satisfy the mobility number (or Shields parameter) similarity, the scale of the waves and current should be adjusted to be much larger than 1/36 for incipient sediment transportation. However, due to our experimental conditions, the bottom current $(U)$ still satisfies $U>U_{c r}$, in which $U_{c r}$ is the critical bottom incipient velocity. Therefore, each test in our experiments is continually conducted at equilibrium scouring (i.e., the maximum scouring depth does not change again).

Figure 2. A sketch of the mobile bed experimental setup for scouring around the jacket-type foundation without protection.

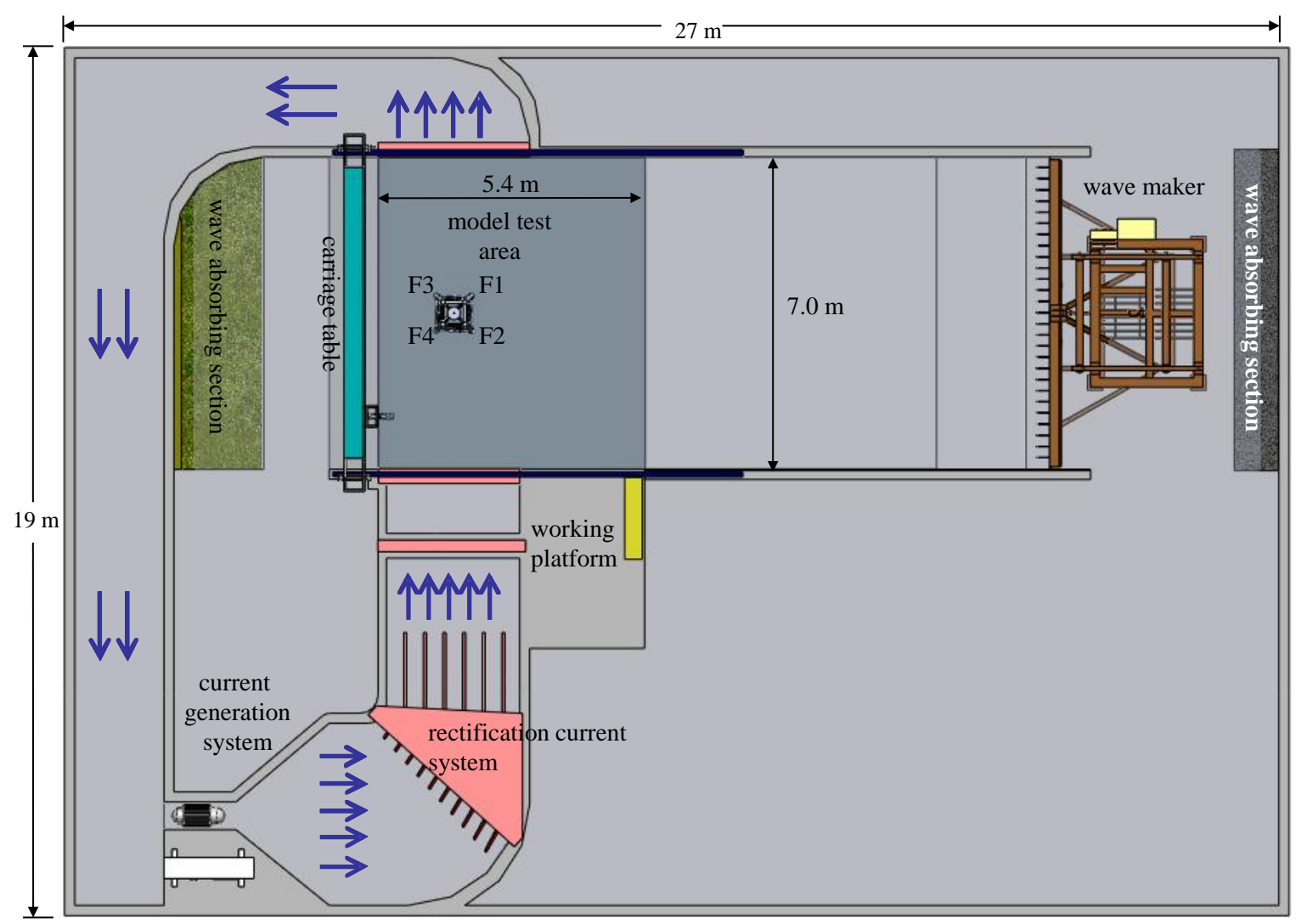

\section{Results and Discussion}

\subsection{Scouring Literature Review}

Scouring is herein considered to be the lowering of the bed in the vicinity of a marine structure due to local accelerations and decelerations of the near-bed velocities and the associated turbulence (vortices), leading to an increase of the local capacity for sediment transportation. Generally, the near-bed flow around the vertical pile consists of a horseshoe vortex generated at the up-current side of the pile and vortices generated at the lee-side of the pile. Currently, with 181 out of 295 foundations of offshore wind turbines, the monopole is the preferred foundation option [8]. Among these foundations, 169 are driven in sandy soils, which can be more or less susceptible to scouring. As a rule of thumb, confirmed by experience with other structures, the scour hole can reach a depth of 1.5-times the pile 
diameter (D). Based on experimental data, Sumer et al. [9] found a circular pile to have a maximum scour depth $\left(d_{\mathrm{s}, \max }\right)$ up to 1.3-times the pile diameter (D). De Bruyn [10] studied the scour process near a vertical pipe in current and wave conditions. The bed material was natural sand with $\mathrm{d}_{50}=0.2 \mathrm{~mm}$. The water depth in the experiment was $0.3 \mathrm{~m}$. The depth-averaged velocity up-current of the pipe was $0.4 \mathrm{~m} / \mathrm{s}$ (mobile bed, $U / U_{c r}>1$ ). The maximum scour depth $\left(d_{\mathrm{s}, \max }\right)$ around the pipe was found to be:

$$
d_{\mathrm{s}, \max } / \mathrm{D}=\alpha
$$

with:

$\alpha=1.3$ for a current alone,

$\alpha=1.0$ for a current and non-breaking waves,

$\alpha=1.9$ for a current and breaking waves.

However, the jacket-type foundation basic design is a non-general, single shape. Therefore, the problem of the scouring of the nearby jacket-type foundation caused by external forces under the waves and current will be a more complex phenomenon than for single vertical piles. Meanwhile, when we consider the local scouring around offshore structures under the interaction of waves and current, a numerical model is still difficult to simulate. Only with on-site monitoring and hydraulic model tests could the scour ranges and the maximum scour depth around the jacket-type foundation be explored.

Table 2. Maximum scour depth around the four piles of the jacket-type foundation (a water depth of $12 \mathrm{~m}$ and $16 \mathrm{~m}$ ) under different hydrodynamic conditions (pile diameter, $\mathrm{D}=2.08 \mathrm{~m}$ ).

\begin{tabular}{cccccccccc}
\hline Test Case & $\boldsymbol{d}_{\mathbf{s} 1} / \mathbf{D}$ & $\boldsymbol{d}_{\mathbf{s} 2} / \mathbf{D}$ & $\boldsymbol{d}_{\mathbf{s} 3} / \mathbf{D}$ & $\boldsymbol{d}_{\mathbf{s} 4} / \mathbf{D}$ & Test Case & $\boldsymbol{d}_{\mathbf{s} 1} / \mathbf{D}$ & $\boldsymbol{d}_{\mathbf{s} 2} / \mathbf{D}$ & $\boldsymbol{d}_{\mathbf{s} 3} / \mathbf{D}$ & $\boldsymbol{d}_{\mathbf{s} 4} / \mathbf{D}$ \\
\hline 12 TLLM & 0.92 & 1.00 & 1.01 & 1.04 & 16 TLLM & 0.54 & 0.43 & 0.59 & 0.47 \\
12TMM & 0.61 & 0.55 & 0.67 & 0.62 & 16 TMM & 0.67 & 0.65 & 0.66 & 0.65 \\
12SLLM & 0.33 & 0.28 & 0.28 & 0.38 & 16 SLLM & 0.37 & 0.32 & 0.33 & 0.36 \\
12SLM & 0.31 & 0.26 & 0.28 & 0.32 & 16 SLM & 0.35 & 0.33 & 0.32 & 0.32 \\
12SMM & 0.21 & 0.23 & 0.22 & 0.28 & 16 SMM & 0.33 & 0.28 & 0.09 & 0.32 \\
12TLLCM & 1.11 & 1.31 & 1.13 & 1.26 & 16 TLLCM & 0.81 & 1.14 & 0.79 & 1.17 \\
12TMCM & 1.02 & 1.19 & 1.00 & 1.09 & 16 TMCM & 0.79 & 0.95 & 0.78 & 0.92 \\
12SLLCM & 0.59 & 1.07 & 0.60 & 1.05 & 16 SLLCM & 0.52 & 1.00 & 0.48 & 0.95 \\
12SLCM & 0.55 & 1.05 & 0.56 & 1.07 & 16 SLCM & 0.48 & 0.94 & 0.48 & 0.97 \\
12SMCM & 0.42 & 0.90 & 0.44 & 0.93 & 16 SMCM & 0.46 & 0.94 & 0.47 & 0.92 \\
\hline
\end{tabular}

Note: the foundation piles' (F1; F2; F3; F4) scour depths are represented as $d_{\mathrm{s} 1}, d_{\mathrm{s} 2}, d_{\mathrm{s} 3}$ and $d_{\mathrm{s} 4}$.

\subsection{Scouring around the Jacket-Type Foundation without Protection}

The length of the scour hole was $4 \mathrm{D}$ (pile diameter; $\mathrm{D}=2.08 \mathrm{~m}$ ) up-wave and $6 \mathrm{D}$ down-wave of the pipe for a combined current and wave. Compared to the monopole foundation, the jacket-type foundation has a more complex structure, but still no further discussion on its maximum scour depth and the length of the scour hole. Therefore, a physical model test study has been performed on the occurrence and prevention of erosion holes (scour) around jacket-type foundations of offshore wind turbines on sandy soils. From Tables 2 and 3, the experimental results show the maximum scour depth 
and the potential impact erosion area around the jacket-type foundation located at a water depth of $12 \mathrm{~m}$ and $16 \mathrm{~m}$ under different hydrodynamic conditions.

Table 3. The potential impact erosion areas around the jacket-type foundation (a water depth of $12 \mathrm{~m}$ and $16 \mathrm{~m}$ ) under different hydrodynamic conditions.

\begin{tabular}{|c|c|c|c|c|c|}
\hline \multirow{2}{*}{ Test Case } & \multicolumn{5}{|c|}{ Impact area of the different scour depth from foundation piles $(D=2.08 \mathrm{~m})$} \\
\hline & $>0.25 \mathrm{D}$ & $>0.5 \mathrm{D}$ & $>0.75 \mathrm{D}$ & $>1.0 \mathrm{D}$ & $>1.2 \mathrm{D}$ \\
\hline 12TLLM & $4 \sim 5 \mathrm{D}$ & $2 \sim 3 \mathrm{D}$ & $1 \sim 2 \mathrm{D}$ & $0.5 \mathrm{D}$ & - \\
\hline $12 \mathrm{TMM}$ & $1.5 \sim 2.5 \mathrm{D}$ & $0.5 \sim 1 \mathrm{D}$ & - & - & - \\
\hline 12TLLCM & $4 \sim 6 \mathrm{D}$ & $3 \sim 4 \mathrm{D}$ & $2 \sim 2.5 \mathrm{D}$ & $1 \sim 1.5 \mathrm{D}$ & $0.5 \mathrm{D}$ \\
\hline 12TMCM & $3 \sim 4 \mathrm{D}$ & $1.5 \sim 3 \mathrm{D}$ & $1 \sim 1.5 \mathrm{D}$ & $0.5 \sim 1 \mathrm{D}$ & - \\
\hline 12SLLCM & $2.5 \sim 4 \mathrm{D}$ & $1 \sim 2 \mathrm{D}$ & $1.5 \mathrm{D}$ & $0.5 \mathrm{D}$ & - \\
\hline 12SLCM & $3 \sim 4 \mathrm{D}$ & $0.5 \sim 2.5 \mathrm{D}$ & $1.5 \mathrm{D}$ & $0.5 \mathrm{D}$ & - \\
\hline 12SMCM & $1 \sim 2 \mathrm{D}$ & $1 \mathrm{D}$ & $0.5 \mathrm{D}$ & - & - \\
\hline 16TLLM & $1 \sim 1.5 \mathrm{D}$ & $0.5 \mathrm{D}$ & - & - & - \\
\hline 16TMM & $1.5 \sim 2.5 \mathrm{D}$ & $0.5 \sim 1 \mathrm{D}$ & - & - & - \\
\hline 16TLLCM & $1.5 \sim 2.5 \mathrm{D}$ & $1 \sim 2 \mathrm{D}$ & $0.5 \sim 1.5 \mathrm{D}$ & $0.5 \mathrm{D}$ & - \\
\hline 16TMCM & $1.5 \sim 2.5 \mathrm{D}$ & $1 \sim 2 \mathrm{D}$ & $0.5 \sim 1 \mathrm{D}$ & - & - \\
\hline 16SLLCM & $1 \sim 2 \mathrm{D}$ & $0.5 \sim 1.5 \mathrm{D}$ & $0.5 \sim 1 \mathrm{D}$ & $0.5 \mathrm{D}$ & - \\
\hline 16SLCM & $1 \sim 2.5 \mathrm{D}$ & $1 \sim 2 \mathrm{D}$ & $1 \sim 1.5 \mathrm{D}$ & - & - \\
\hline 16SMCM & $1.5 \sim 2 \mathrm{D}$ & $1 \sim 1.5 \mathrm{D}$ & $1 \sim 1.2 \mathrm{D}$ & - & - \\
\hline
\end{tabular}

Figure 3. The evolution of the scour depth around the four piles of the jacket-type foundation for the case, 12TLLCM, (12, 12-m water depth; T, 100-year return period typhoon wave; LL, lower low water level; C, current; M, mobile bed).
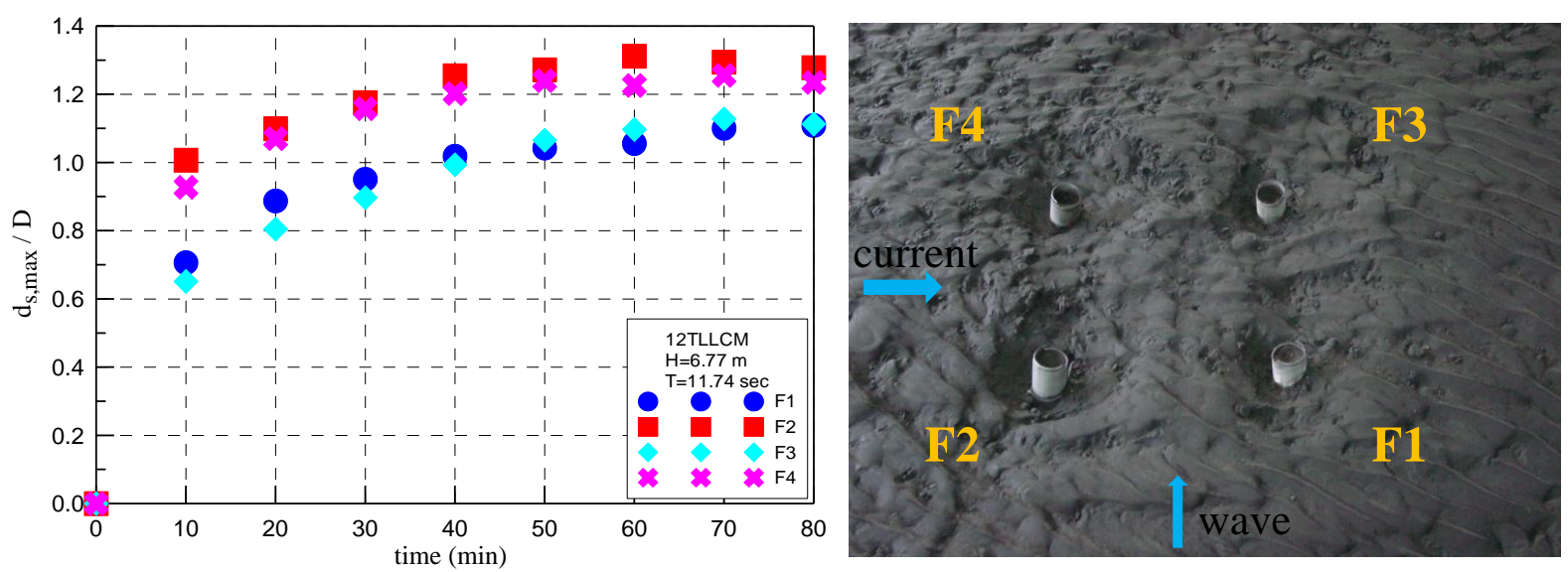

For the jacket-type foundation located at a water depth of $12 \mathrm{~m}$, case $12 \operatorname{TLLCM}(12$, 12-m water depth; T, 100-year return period typhoon wave; LL, lower low water level; C, current; M, mobile bed) is the most serious scour event exposed to the lowest water level, the action of the combined current and the 1:100 year return period typhoon wave. The maximum scour depths around the four piles of the jacket-type foundation are $d_{s 1} / \mathrm{D}=1.11, d_{\mathrm{s} 2} / \mathrm{D}=1.31, d_{\mathrm{s} 3} / \mathrm{D}=1.13$ and $d_{\mathrm{s} 4} / \mathrm{D}=1.26$, respectively. Figures 3 and 4 show the evolution of the maximum scouring depth and the potential impacted erosion area around four piles of the jacket-type foundation under the case, 12TLLCM. In this experiment, the 
angle between the incident wave and the current is $90^{\circ}$. The results show that more serious scouring will be induced at piles $d_{\mathrm{s} 2}$ and $d_{\mathrm{s} 4}$ on the up-current side of the foundation. From the observations, it is estimated that the length of the scour holes around the four piles of the foundation is approximately up to 4 6 times the pile diameter. However, when the foundation location changed to a 16-m water depth, the maximum scouring depth and the length of the scour hole are less than those obtained from the tests at a 12-m water depth (see Tables 2 and 3). This is because, not only erosion, but also redeposition will occur within the experimental process under the location with a 16-m water depth.

Figure 4. The $2 \mathrm{D}$ and $3 \mathrm{D}$ potential impact erosion area and scouring around the four piles with the jacket-type foundation under the case, 12TLLCM (80 min, i.e., after finishing the test).
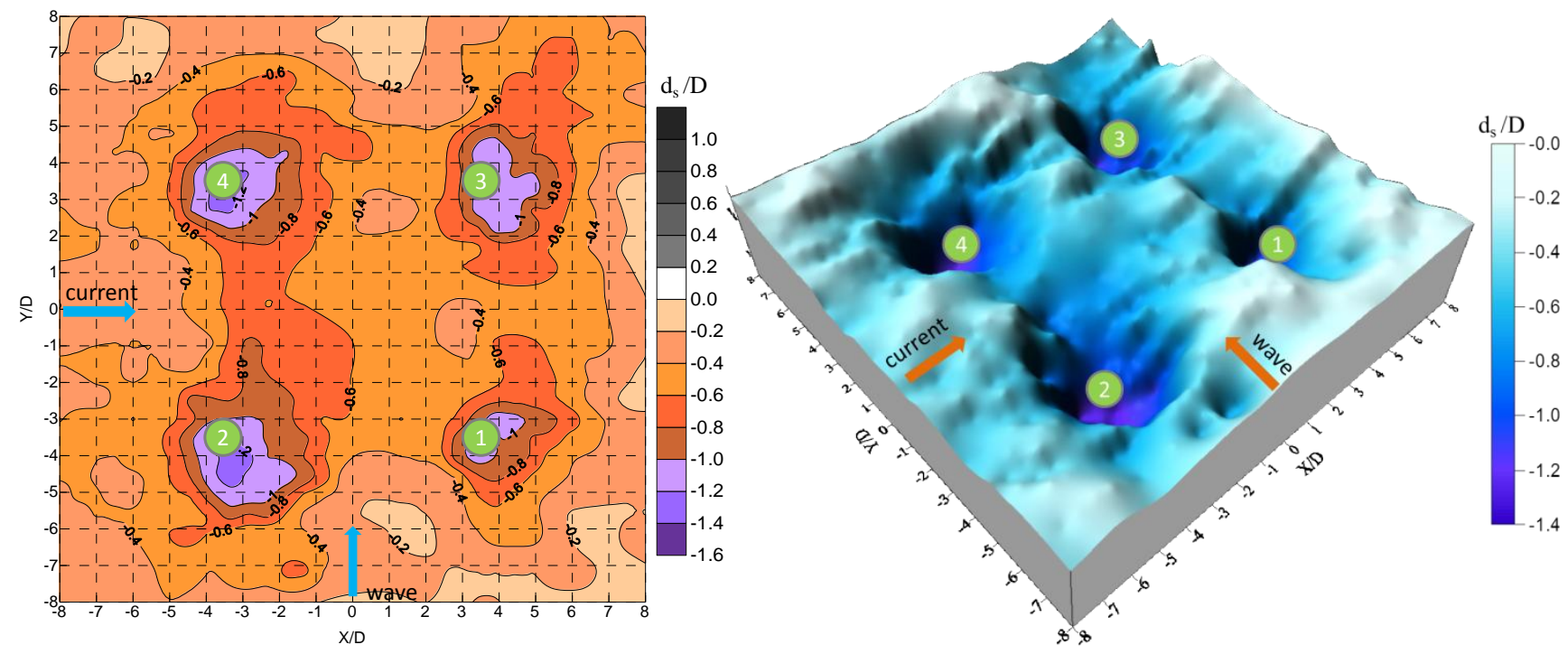

From the experimental results, it is shown that the maximum scour depth usually occurs in the up-current or up-wave side of the jacket-type foundation. The scour differences resulting from the $12 \mathrm{~m}$ and the $16 \mathrm{~m}$ water depth come from pre-wave breaking before the jacket-type foundation at the $16 \mathrm{~m}$ water depth and the redeposition of sedimentation.

\subsection{Hard Scour Protection for Jacket-Type Foundation}

When the occurrence or uncertainties of a local scour hole around the foundation of a wind turbine are not desired, preventive or remedial countermeasures can be applied. Almost all of today's knowledge about scouring behavior and the strategies for scour protection is based on physical experiments carried out in flumes in co-directional waves and current, with two-dimensional waves (for example, those of Sumer and Fredsøe [11]). Typically, traditional hard scour protection will be realized by using layers of natural and crushed rock, which increase in size as one goes up from the seabed. The lowest layer of rock, which is small enough to restrain the soil, can be replaced by a geo-textil [12].

Therefore, based on the analysis from the former NSWB experimental results, one of the suitable traditional hard scour protections for the jacket-type foundation of an offshore wind turbine is firstly proposed and shown in Figure 5. The proposed hard scour protection consists of: 
(1) a precast concrete block: $2 \mathrm{~m} \times 2 \mathrm{~m} \times 1 \mathrm{~m}$,

(2) armor stones: 0.5 1.0 ton, with a layer thickness of $1.4 \mathrm{~m}$,

(3) filter stones: $5 \sim 100 \mathrm{~kg}$, with a layer thickness of $0.6 \mathrm{~m}$,

(4) geo-textile (No. 4).

Figure 5. A sketch of the proposed hard scour protection for the jacket-type foundation.

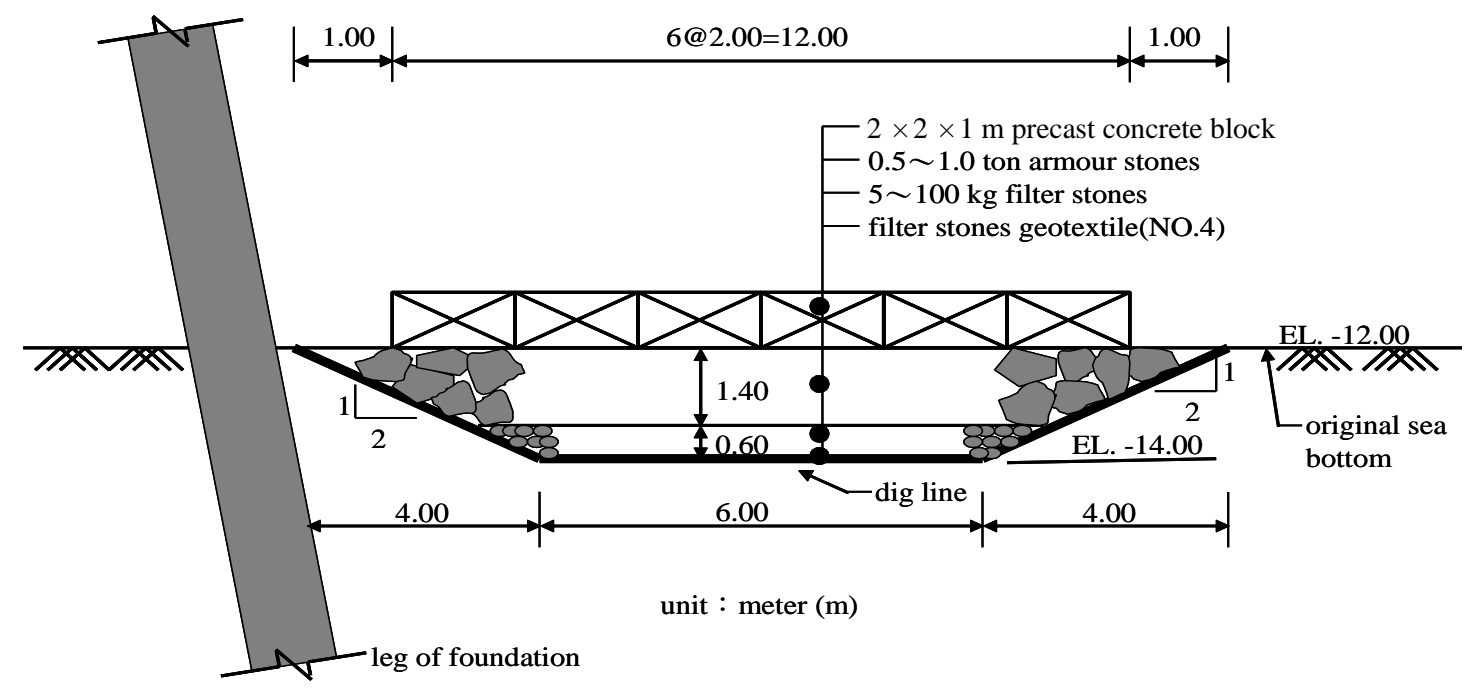

Figure 6. The experimental setup of the hard scour protection for the jacket-type foundation.

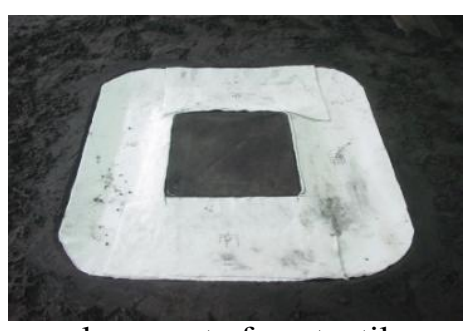

placement of geotextile

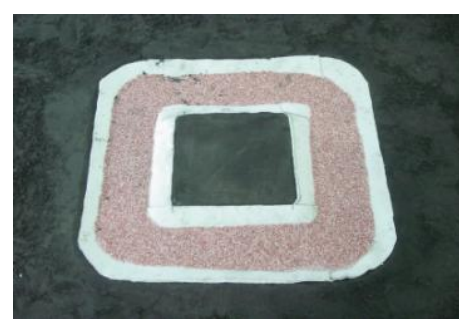

placement of filter stones

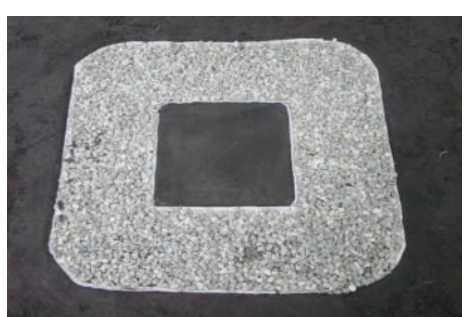

placement of armour stones

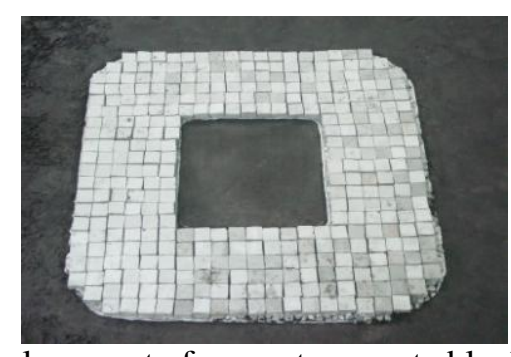

placement of precast concrete block

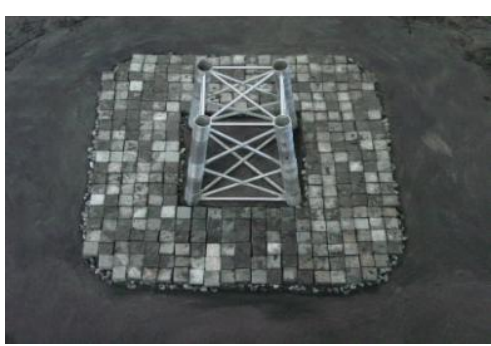

model of scour protection

The edge of this proposed hard scour protection attains a slope of $1 \mathrm{~V}: 2 \mathrm{H}$ (V, vertical; $\mathrm{H}$, horizontal). The experimental setup of the hard scour protection is shown in Figure 6. If the rubblemound structures and wave absorbers are modeled with the stone sizes geometrically reduced from the prototype scale, there will be relatively less wave transmission through the model structure. Frictional losses are greater in the model, as the wave travels through the structure, and this becomes particularly pronounced at the scales used for harbor models [13]. This scale effect is countered by increasing the size of the model stones over that dictated by geometric scaling. The initial bed levels and scour protection block level are checked with bed profiles taken by a calibrated automatic bottom profiler. Pre- 
and post-test profiles are used to identify any settlement and stability in the precast concrete block and scouring in the surrounding seabed. From Figures 7 and 8, the results show that the protection block maintained the initial level and remained stable. Nevertheless, there is scouring of the bed outside the protection by up to $0.59 \mathrm{D}$ and inside the foundation by up to $0.86 \mathrm{D}$ locally. However, a four-layer hard scour protection is tested and found to be effective in preventing scouring around the jacket-type foundation of an offshore wind turbine.

Figure 7. Comparison of maximum scour depth between the case, 12TLLCM (without scour protection), and the case, 12TLLCPM (with hard scour protection).

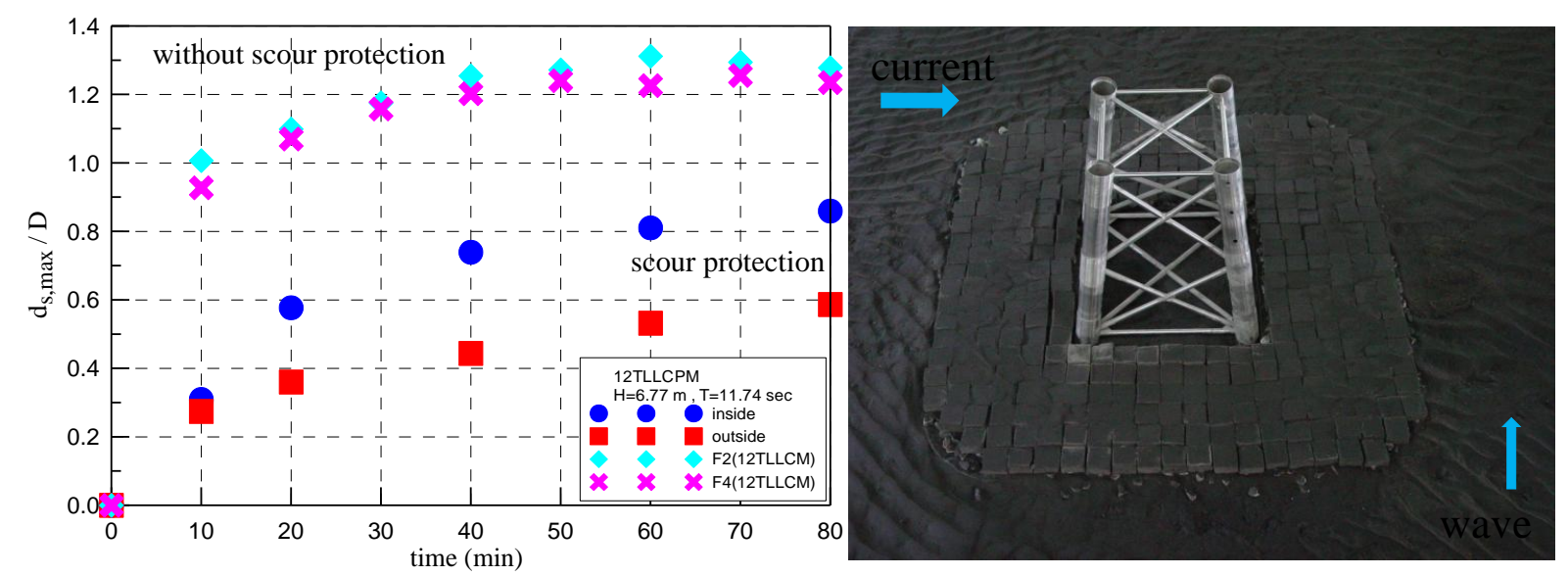

Figure 8. The potential impact erosion areas around the hard scour protection for the jacket-type foundation under the case, 12TLLCPM.

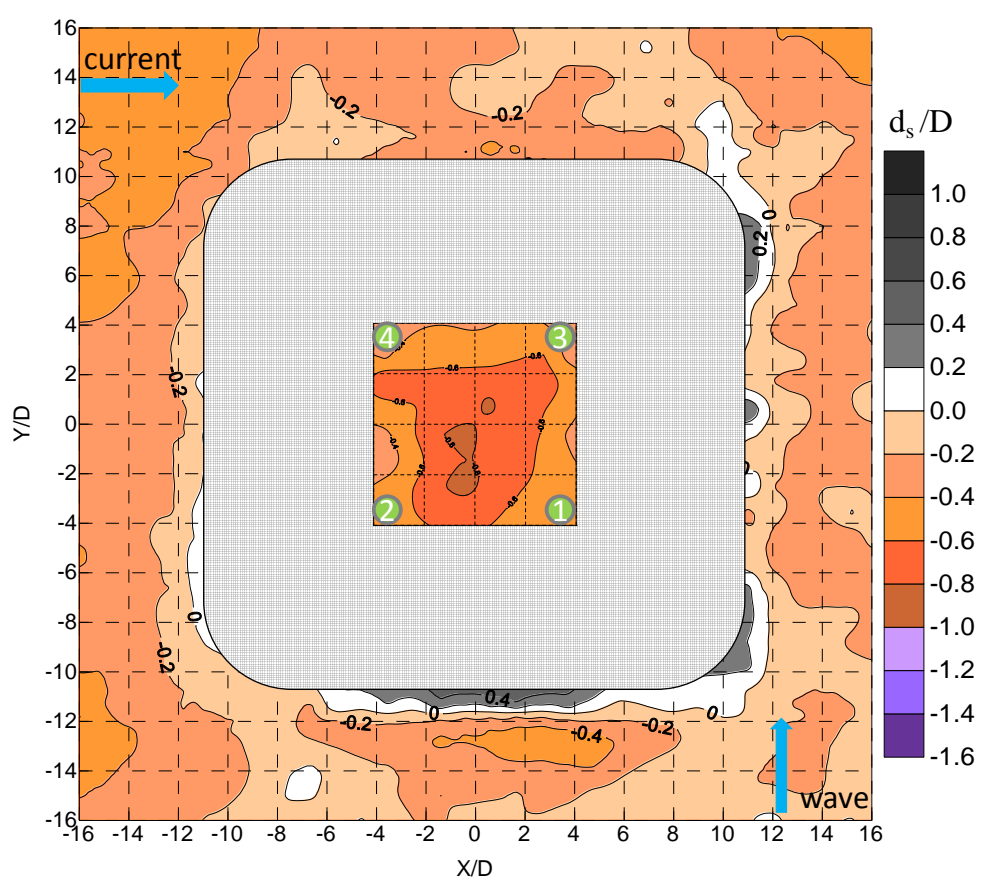

\subsection{Soft Scour Protection for Jacket-Type Foundation}

Taiwan has plenty of offshore wind power resources in the western coastal water areas, but they have not yet been utilized, unlike the resources of land wind, which mostly has been applied and 
arranged. The government expected the renewable proportion of energy to reach the goal of $15.1 \%$ in 2025, including 5.3\% from offshore wind power. This reveals that offshore wind power is the most important and urgent renewable energy, which increases the most and is larger than expectations. However, this amount of electricity from offshore wind energy requires a sizable coastal water area, which is currently shared by various users, including fishermen, shipping lines, recreation, tourism, and others. Thus, public acceptance of offshore wind farms is very important for the success of offshore wind energy development in the western Taiwan coastal water area, and it is necessary for developers to explore the concerns of these different users. Besides, various stakeholders are involved in the marine environment and have different opinions about offshore wind energy. Fishermen are an important stakeholder group, because the livelihoods of commercial fishermen could be significantly affected by the installation of offshore wind turbines. Taking Germany as an example, the coastline of Germany is very short, and the overlapping usage of the offshore water area is very frequent. In order to reduce the conflicts between users, multiple usage policies, which combine offshore wind farms and aquaculture, could be adopted by using the structure of offshore wind farms to fasten aquaculture to prevent cultivated organisms from sinking because of the sea current [14]. Thus, this study also considers the concept of the usage of integrative coastal space to combine offshore wind turbines and coastal cage nets, to analyze different distances and optimum cage net depths and, furthermore, to discuss these factors of coastal cage nets, which could slow down the erosion around wind turbine foundation. The cage net diameter is $18 \mathrm{~m}$, which is the same as the outer width (W) of the jacket-type foundation. The tested cage net depths are $4 \mathrm{~m}, 8 \mathrm{~m}$ and $12 \mathrm{~m}$, which are 1/4, 2/4 and 3/4 of the water depth (h) of $16 \mathrm{~m}$ in the field site. Meanwhile, the local stakeholders' opinion about combining offshore wind energy with coastal cage net aquaculture should be deeply understood. Two series of physical model tests with the same 1:36 scale fixed-bed and mobile bed experiments were performed in this soft scour protection study. The aim of the first test series is to investigate the optimum location and depth of coastal cage nets to reduce the hydrodynamic conditions (100 return period typhoon wave or current) around the jacket-type foundation by the fixed-bed experiments. Another test is aimed at differentiating the greatest magnitude of local scour and potential scour areas in the sand bed around the jacket-type foundation with the optimum location and depth of the coastal cage nets by mobile bed experiments. Meanwhile the Delphi method is used to analyze the related stakeholders' opinions about the integration of offshore wind energy and coastal cage net aquaculture in the intermediate water depth and their experience and knowledge to reconcile the asymmetry between government and communities.

The layout of the $27 \mathrm{~m} \times 19 \mathrm{~m}$ wave-current basin for the fixed-bed experimental setup is shown in Figure 9. The wave flume passes from right to left, and the current-generation flume circulates from the downside to the upside. The test area with the models of the jacket-type foundation and coastal cage nets within the water depth of $16 \mathrm{~m}$ in the field site is at the junction of these two flumes. The physical modeling is carried out in this wave-current basin at the Tainan Hydraulics Laboratory (THL) with a scale of 1:36. Froude's law is obeyed in the fixed-bed experiment. The equipment and measurement system used in this experiment include an irregular wave maker, a current-generation system, electrical capacitance wave gauges and acoustic doppler velocimeters (ADV). From the fixed-bed experimental results, it is shown that the up-current optimum location of coastal cage nets in front of the jacket-type foundation can have a good effect at reducing the current speed under the 
conditions that the distance between the cage net and foundation is two-times the foundation width (W). However, with the up-wave location of the coastal cage net in front of the jacket-type foundation, the wave attenuation effect near the wind turbine foundation is not so obvious. From the fixed-bed experimental results, the optimum cage net water depth is up to 0.75 (3/4 h, 12-m cage net depth insitu) for reducing the current speed.

Figure 9. A sketch of the experimental setup for the jacket-type foundation and coastal cage net.

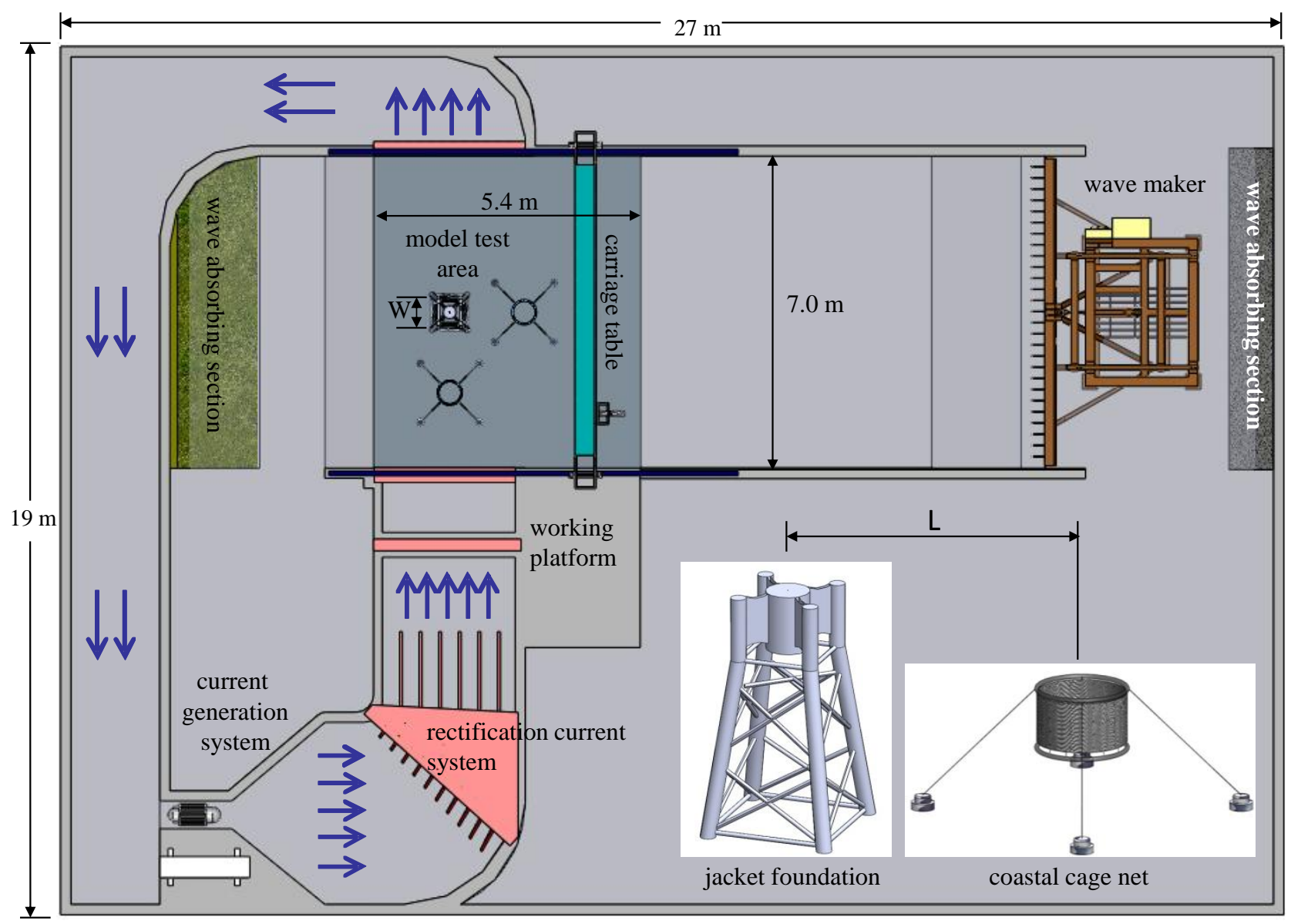

After the fixed-bed experimental tests, the mobile experimental study on the soft scour protection for the jacket-type foundation for offshore wind turbines is further conducted. The sediment used in this movable-bed experiment is light density coal (the specific gravity of coal, $\gamma_{c}=2.02$ ) of a median grain size $d_{50}=0.15 \mathrm{~mm}$, and the model sand bed is $0.35 \mathrm{~m}$ deep, $7.0 \mathrm{~m}$ long and $5.4 \mathrm{~m}$ wide. The equipment and measurement system used in this mobile bed experiment include the same system used in the fixed-bed experiment together with the ultrasonic bottom profiler moved by the carriage table. From Table 4 and Figure 10, the evolution of the maximum scour depth with the different test conditions for the jacket-type foundation is shown. For the current-alone case (a current of $1.5 \mathrm{~m} / \mathrm{s}$ ), the scour hole can reach a maximum depth $\left(d_{\mathrm{s}, \max }\right)$ of 1.37-times the pile diameter (D) of the jacket-type foundation without the coastal cage net. However, if we locate the coastal cage net in front of the wind turbine on the up-current side optimum position $(2 \mathrm{~W})$, the maximum scour depth can be reduced to $1.08 \mathrm{D}$, and the redeposition phenomenon occurred inside the jacket-type foundation; see Figure 11. Regarding the combined typhoon wave and current loading tests, the maximum scour depth 
can be from $1.17 \mathrm{D}$ (without the cage net) to $0.75 \mathrm{D}$ (one cage net at the up-current side) or $0.71 \mathrm{D}$ (one cage net at the up-current side, another one at the up-wave side). Therefore, the cage net can reduce the current rate and scouring around the jacket-type foundation.

Table 4. The maximum scour depth around the four piles of the jacket-type foundation and the coastal cage net (a water depth of $16 \mathrm{~m}$ ) under different hydrodynamic conditions $(\mathrm{D}=2.08 \mathrm{~m})$.

\begin{tabular}{|c|c|c|c|c|c|c|c|c|c|}
\hline Test Case & $d_{\mathrm{s} 1} / \mathrm{D}$ & $d_{\mathrm{s} 2} / \mathrm{D}$ & $d_{\mathrm{s} 3} / \mathrm{D}$ & $d_{54} / \mathrm{D}$ & Test Case & $d_{\mathrm{s} 1} / \mathrm{D}$ & $d_{\mathrm{s} 2} / \mathrm{D}$ & $d_{\mathrm{s} 3} / \mathrm{D}$ & $d_{\mathrm{s} 4} / \mathrm{D}$ \\
\hline $\begin{array}{c}\text { current of } 0.5 \\
\mathrm{~m} / \mathrm{s}\end{array}$ & 0.35 & 0.66 & 0.40 & 0.73 & $\begin{array}{l}0.5 \mathrm{~m} / \mathrm{s} \\
\text { cage net }\end{array}$ & 0.26 & 0.59 & 0.31 & 0.53 \\
\hline $\begin{array}{c}\text { current of } 1.0 \\
\mathrm{~m} / \mathrm{s}\end{array}$ & 0.61 & 1.12 & 0.76 & 1.11 & $\begin{array}{l}1.0 \mathrm{~m} / \mathrm{s} \\
\text { cage net }\end{array}$ & 0.52 & 0.91 & 0.53 & 0.87 \\
\hline $\begin{array}{c}\text { current of } 1.5 \\
\mathrm{~m} / \mathrm{s}\end{array}$ & 0.70 & 1.24 & 0.62 & 1.37 & $\begin{array}{l}1.5 \mathrm{~m} / \mathrm{s} \\
\text { cage net }\end{array}$ & 0.46 & 1.08 & 0.46 & 0.87 \\
\hline $\begin{array}{l}16 \text { TLLCM } \\
1 \text { cage net* }\end{array}$ & 0.75 & 0.65 & 0.71 & 0.64 & $\begin{array}{l}\text { 16TLLCM } \\
2 \text { cage net** }\end{array}$ & 0.70 & 0.48 & 0.45 & 0.71 \\
\hline
\end{tabular}

* cage net located at the up-current side; ** cage nets located at the up-current side and the up-wave side.

Figure 10. The maximum scour depths under the different test conditions for the jacket-type foundation and coastal cage net.

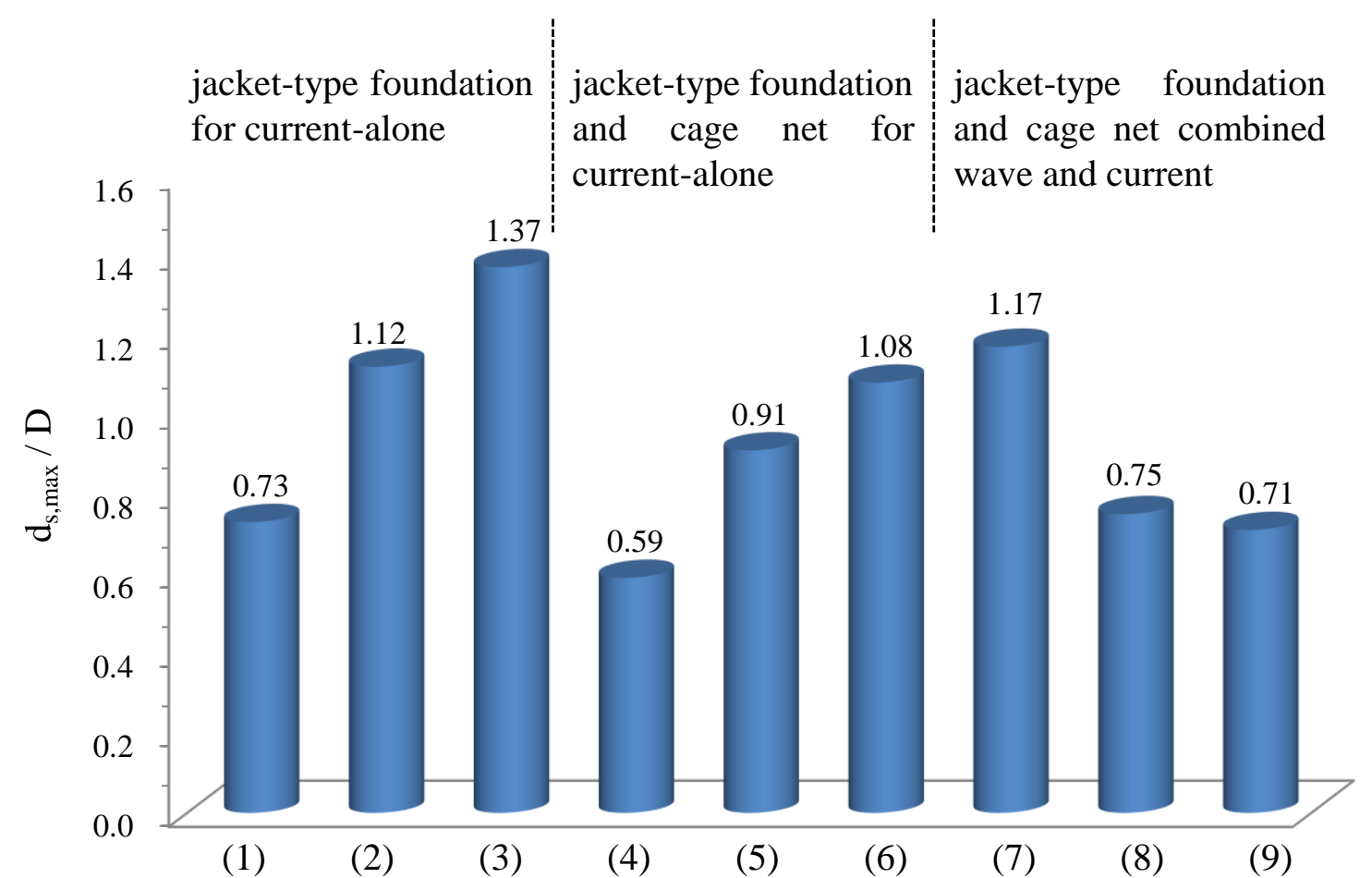

Note: (1) current of $0.5 \mathrm{~m} / \mathrm{s}$; (2) current of $1.0 \mathrm{~m} / \mathrm{s}$; (3) current of $1.5 \mathrm{~m} / \mathrm{s}$; (4) current of $0.5 \mathrm{~m} / \mathrm{s}+$ cage net; (5) current of $1.0 \mathrm{~m} / \mathrm{s}+$ cage net; (6) current of $1.5 \mathrm{~m} / \mathrm{s}+$ cage net; (7) typhoon wave + current of $1.0 \mathrm{~m} / \mathrm{s} ;(8)$ typhoon wave + current of $1.0 \mathrm{~m} / \mathrm{s}+$ cage net (up-current side); (9) typhoon wave + current of $1.0 \mathrm{~m} / \mathrm{s}+2$ cage net (up-current side and up-wave side). 
Figure 11. The potential impact erosion area and scouring around four piles of the jacket-type foundation and cage net under the current-alone case (a current of $1.5 \mathrm{~m} / \mathrm{s}$ ).
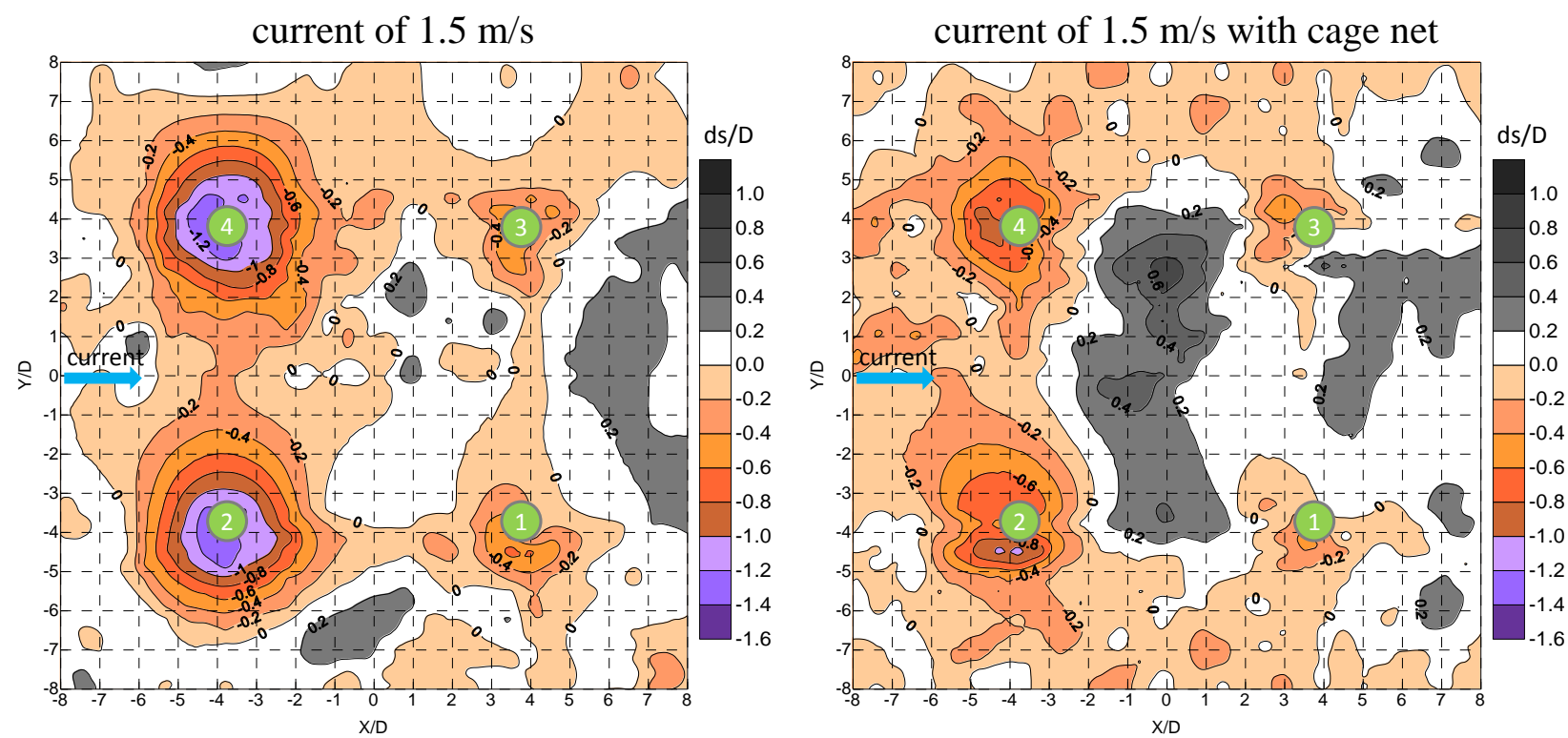

Besides the above experimental studies, this study also has made a preliminary analysis for stakeholders' opinions on offshore wind energy and coastal aquaculture to understand the real demand for adjusting the dilemma of the marine space utilization in the western Taiwan coast. The stakeholders' opinions are collected from four groups, including government, offshore wind farm developers, environmental groups and residents. From this preliminary feasible analysis for stakeholders' opinions, the results show that the four groups can accept the concept of an integration of offshore wind farms and cage net aquaculture for the western Taiwan coastal water utilization. However, a detailed layout for the integration of offshore wind farms and coastal aquaculture should be investigated in the near future.

\section{Conclusions}

This paper presents the results of a study regarding the scouring around the jacket-type foundation, which is being considered to be used in the mid-western coastal wind farm development in Taiwan. The scouring and scour mitigation investigation is carried out in a wave-current basin to provide a deep understanding of the flow-structure interaction. The ratio of the maximum scour depth-to-pile diameter (D) of the jacket-type foundation and the potential impacted scour area can be obtained from the results of the physical model test. Meanwhile, a four-layer traditional hard scour protection is tested and found to be effective in preventing scouring around the jacket-type foundation of an offshore wind turbine. Although it is common practice to apply scour protection at sites with a potential local scouring, the analysis of this study indicates that the function of the protection is likely to provide a technically acceptable solution. Furthermore, the study of the designed solutions with and without scour protection will be investigated by a comparison with respect to the technical feasibility, risks and costs in the near future.

Meanwhile, this study on the integration of the jacket-type foundation and coastal cage aquaculture as a soft scour protection countermeasure is helpful toward the substantial development of the coastal 
water area, and it could be an important reference for future coastal integration development, to provide related organizations with the implementation of the multiple usage of the coastline, integrating offshore wind energy and coastal aquaculture facilities. Furthermore, when building the related stakeholders' evaluation system, it is suggested to investigate in the near future detailed community information to achieve a balance between coastal development and the livelihood of the residents.

\section{Acknowledgments}

The authors would like to thank the support from the National Science Council of Taiwan under a grant (No. NSC 101-2221-E-006-054). Meanwhile, the financial support from Sinotech Engineering Consultants, Ltd., and the Taiwan Power Company (TPC) is also gratefully acknowledged.

\section{Author Contributions}

Conceived and designed the experiments: H.-H.C. R.-Y.Y. H.-H.H.; Performed the experiments: H.-H.C.; Analyzed the data: H.-H.C.; Wrote the paper: H.-H.C. R.-Y.Y. H.-H.H.

\section{Conflicts of Interest}

The authors declare no conflict of interest.

\section{References}

1. Hansen, E.A.; Simonsen, H.J.; Nielsen, A.W.; Pedersen, J.; Høgedal, M. Scour protection around offshore wind turbine foundations, full-scale measurements. In Proceedings of the European Offshore Wind Conference, Berlin, Germany, 4-6 December 2007; pp. 132-138.

2. Stahlmann, A.; Schlurmann, T. Investigations on Scour Development at Tripod Foundations for Offshore Wind Turbines: Modeling and Application. Coast. Eng. Proc. 2012, 1, doi:10.9753/icce. v33.sediment.90.

3. Bryson, J.M. Strategic Planning for Public and Nonprofit Organizations; Jossey-Bass: San Francisco, CA, USA, 1995.

4. Backoff, R.W.; Nutt, P.C. A process for strategic management with specific application for the nonprofit organization. In Strategic Planning, Treats and Opportunities for Planners; Bryson, J.M., Einsweiler, R.C., Eds.; Planners Press: Chicago, IL, USA, 1988.

5. Borrini-Feyerabend, G.; Farvar, M.T.; Nguinguiri, J.C.; Ndangang, V.A. Co-management of Natural Resources: Organising, Negotiating and Learning-by-Doing; GTZ and IUCN, Kasparek Verlag: Heidelberg, Germany, 2000.

6. Jentoft, S.; Son, T.C.; Bjorkan, M. Marine Protected Areas: Agovernance System Analysis. Hum. Ecol. 2007, 35, 611-622.

7. Hughes, S.A. Physical Models and Laboratory Techniques in Coastal Engineering; World Scientific: Singapore, Singapore, 1993.

8. Schachner, J. Power Connections for Offshore Wind Farms. Master's Thesis, Delft University, Delft, The Netherlands; University of Leoben, Leoben, Austria, January 2004. 
9. Sumer, B.M.; Fredsøe, J.; Christiansen, N. Scour around vertical pile in waves. ASCE J. Waterw. Port Coastal Ocean Eng. 1992, 118, 15-31.

10. De Bruyn, C.A. Scour Near Platform Pier due to Current and Breaking Waves; Department of Coastal Engineering, Delft University Technology: Deft, The Netherlands, 1988.

11. Sumer, B.M.; Fredsøe, J. The Mechanics of Scour in the Marine Environment; World Scientific: Singapore, Singapore, 2002.

12. Den Boon, J.H.; Sutherland, J.; Whitehouse, R.; Soulsby, R.; Stam, C.J.M.; Verhoeven, K.; Hogedal, M.; Hald, T. Scour behaviour and scour protection for monopile foundations of offshore wind turbines. In Proceedings of the 2004 European Wind Energy Conference, London, UK, 22-25 November 2004; European Wind Energy Association [CD-ROM]: London, UK, 2004; p. 14.

13. Hudson, R.Y.; Herrmann, F.A.; Sager, R.A.; Whalin, R.W.; Keulegan, G.H.; Chatham, C.E.; Hales, L.Z. Coastal Hydraulic Models; Special Report No. 5; U.S. Army Engineer Waterways Experiment Station: Vicksburg, MS, USA, 1979.

14. Buck, B.H. Experimental trials on the feasibility of offshore seed production of the mussel Mytilusedulis in the German Bight: Installation, technical requirements and environmental conditions. Helgol. Mar. Res. 2007, 61, 81-101.

(C) 2014 by the authors; licensee MDPI, Basel, Switzerland. This article is an open access article distributed under the terms and conditions of the Creative Commons Attribution license (http://creativecommons.org/licenses/by/3.0/). 